\title{
Suggested Study as a Treatment Protocol for Coronavirus
}

\author{
Shahin, M. I* \\ Zoology Department, Faculty of Women for Arts, Science and Education, Ain Shams University
}

\section{$\underline{\text { Abstract }}$}

Coronaviruses are a large family of RNA viruses without segment, positive-sense RNA genomes and single-stranded, which cause illnesses. The disease ranging from mild in most people to diseases that is more dangerous. It may progress to pneumonia, acute respiratory distress syndrome and finally failure in vital function. Many people did not show symptoms of the disease. Clinical laboratory finding are low white cell counts with high rate of C-reactive protein. Chloroquine has positive antiviral effects on virus infection of primitive cells. In addition, these inhibitory effects were seen when the drug was used before and after exposure to the virus, this is important for both the preventive and curative architecture as well as therapeutic advantage of chloroquine. Meclizine and pyridoxine hydrochloride are considered strong anti-inflammatory, which help in controlling cytokine storm. Treatment by mixture of chloroquine, corticosterone, meclizine and pyridoxine may be protecting against blood clotting, which limits the spread of the disease. Accordingly, chloroquine, corticosterone, meclizine and pyridoxine can be used as prevention and treatment against pathogenic viral infections.

\section{Key words: Coronavirus, Pyridoxine, Meclizine, Chloroquine, Corticosterone}

\section{Introduction}

Coronaviruses are the large family of RNA viruses. The dangerous of this virus lies in the occurrence of severe infections and elevation in the death rate. The structure of the virulent virus is couple strongly to the SARS-CoV strain to produce positive-sense RNA formation. The illness termed coronavirus 19 spread tremendously quickly from the main area in China, hence the World Health Organization adopting it as a global epidemic disease [1].

The first discovered of coronavirus was infectious bronchitis virus (IBV) that cause's respiratory infection in chickens and the human coronavirus, human coronavirus-OC43 (HCoV-OC43) and human coronavirus-229E (HCoV-229E), that cause humans infection with colds [2]. Since the emergence of HCoV-OC43, HCoV-229E and several other human coronavirus such as acute respiratory syndrome-CoV (SARS-CoV) found in 2002, middle east respiratory syndrome-coronavirus (MERS-CoV) in 2012, H coronavirus-NL63 in 2004 and HCoV-HKU1 in 2005. Since late November 2019, some reports have emerged indicating the presence of patient in China, specifically Wuhan, with acute respiratory infections. [3]. Studies have proven that one of the factors causing the respiratory disease is the new coronavirus.

*Corresponding author: Shahin, M. I, Zoology Department, Faculty of Women for Arts,

Science and Education, Ain Shams University.

E-mail: semsma.mona2000@yahoo.com 
The disease caused by SARS-CoV-2 has been named COVID-19. Dealing with CoVs has been seen as an annoyance, but not as a dangerous virus. Matters became more complicated after the emergence of the SARS virus, which resulted in severe diseases and deaths, in 2002-2003 [4]. It differs from all human coronaviruses that infect the respiratory system resulting in severe respiratory symptoms such as high temperatures, shortness of breath and severe coughing. [5]

By examination, it was found that the coronavirus is an encapsulated virus (envelope means a double layer of lipid is derived from cell membrane of the host) . The structure of virus formed primarily of structural proteins such as spike $(\mathrm{S})$, membrane $(\mathrm{M})$, envelope $(\mathrm{E})$, nucleocapsid $(\mathrm{N})$ proteins and hemagglutinin-esterase (HE) protein in some beta coronaviruses. The $\mathrm{S}, \mathrm{M} \& \mathrm{E}$ proteins included in the viral envelope; however, $\mathrm{N}$ protein interacts with the viral RNA and is located in the core of the viral particle, forming the nucleocapsid [6]. Protein S is a densely glycosylated protein that contributes to homologous mutations on the surface of the viral particle and mediates viral entry into host cells. [7]. In some coronavirus, each monomer of the homotimeric S protein present as two subunits (S1 \& S2) due to cleavage of $S$ protein by host furin-like proteases through viral replication [8]. However, in some CoVs including SARS-CoV, the S protein forms the S1 and S2 domains, and remains intact on the viral particles, as it only cleaves into the internal vesicles during entry into the virus. [9].

Membrane protein (M) is also considered one of the most important proteins in the release structure, as it is present in more quantities than other proteins in viral particles: In contrast, the envelope protein $(\mathrm{E})$ is present in small quantities within the virion and works to release viral particles from the host cells $[10,11]$. Protein $(\mathrm{N})$ is necessary for packing viral RNA into viral particles through viral assembly as it binds to viral RNA. [12]. The difference in abundance may due to, the $\mathrm{M}$ protein which is responsible for giving the virus its basic shape, and it is necessary in terms of importance with the E protein in the process of virus assembly and also in the formation of mature viral sheaths. (Figure, 1). Protein (HE) is found on the surface of some beta corona viruses. It consists of heme gluten, somewhat similar to the influenza virus, in that it has acetyl esterase activity [13]. It turns out that $\mathrm{HE}$ characteristic may enhance the entry and pathogenic of coronaviruses that include such protein in their viral structure (Figure, 1).

Some researchers are studying the different ways of the on the different ways the virus spreads. Nevertheless, the researchers found that one of the most important way for transmit viruses in the respiratory system, such as mucous secretions [13]. The different 
types of viral diseases vary in the spread of disease. Some flu symptoms such as coughing and sneezing may cause droplets to fly into the air. It is also one of the most important methods of transmitting the virus between individuals by touching. Touching surfaces that have been exposed to the virus causes transmission of infection when touching the nose, mouth or eyes. Contact with faces may help in the spread of some animal coronaviruses, such as feline coronavirus (FCoV). It was not clear if this was related to the spread of human coronavirus [14]. The National Institutes of Health (NIH) has found that some people are more vulnerable than others in developing complications from COVID-19. In addition, corona viruses infect some people at some time during their lifetime.

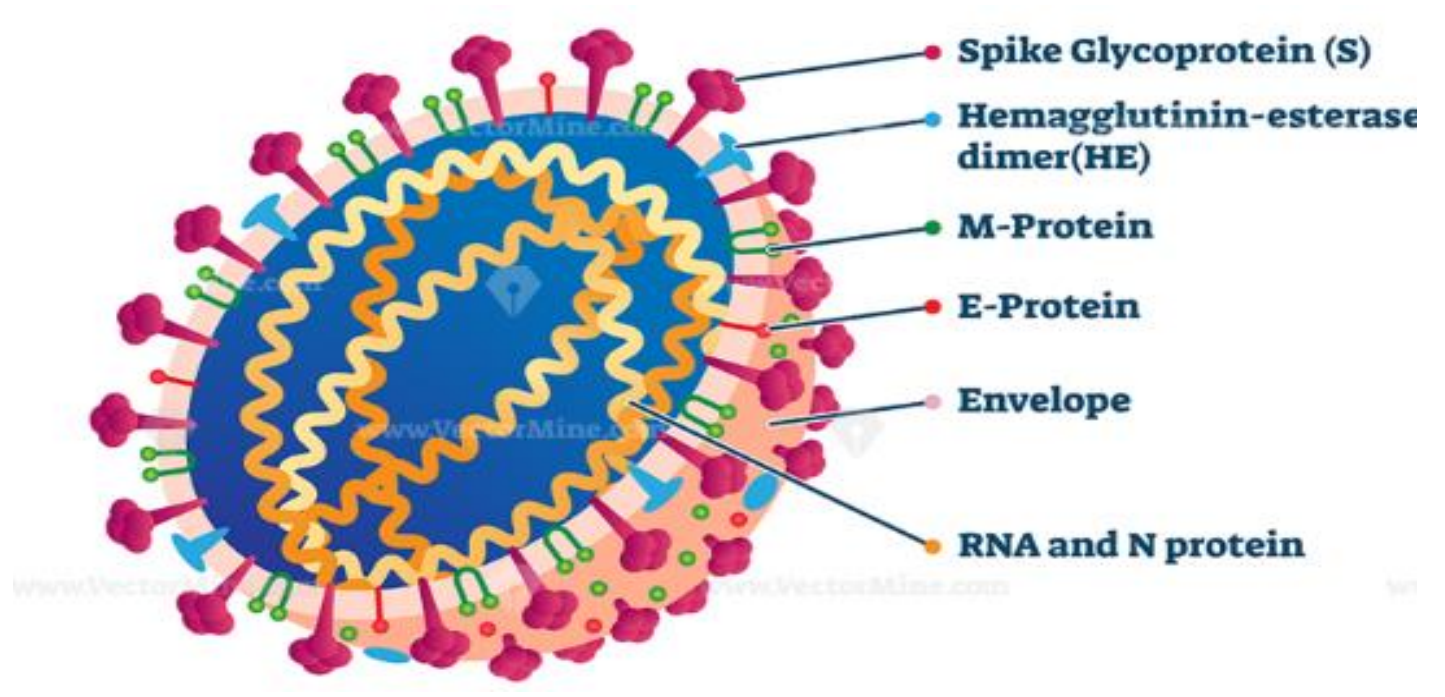

Figure (1): Structure of Coronavirus [15].

Coronavirus life cycle steps are attachment and entry, homologous protein expression, transcription finally assembly and release (Figure, 2). The symptoms of the Coronavirus are similar to the symptoms of influenza and usually appear within a period of 25 days after infection with the virus and at the beginning of the disease mild. Symptoms vary between people, and viruses can be fatal. These symptoms include sneezing, runny nose, cough, diarrhea, fever in rare cases and asthma. Research continued in various countries of the world in order to produce an anti-virus vaccine to treat COVID-19 patients. Until now, no highly effective vaccine was found without side effects, so that it could be adopted as a preventive measure against the virus. Repositioning this medication may be the best solution to control this epidemic infection. 


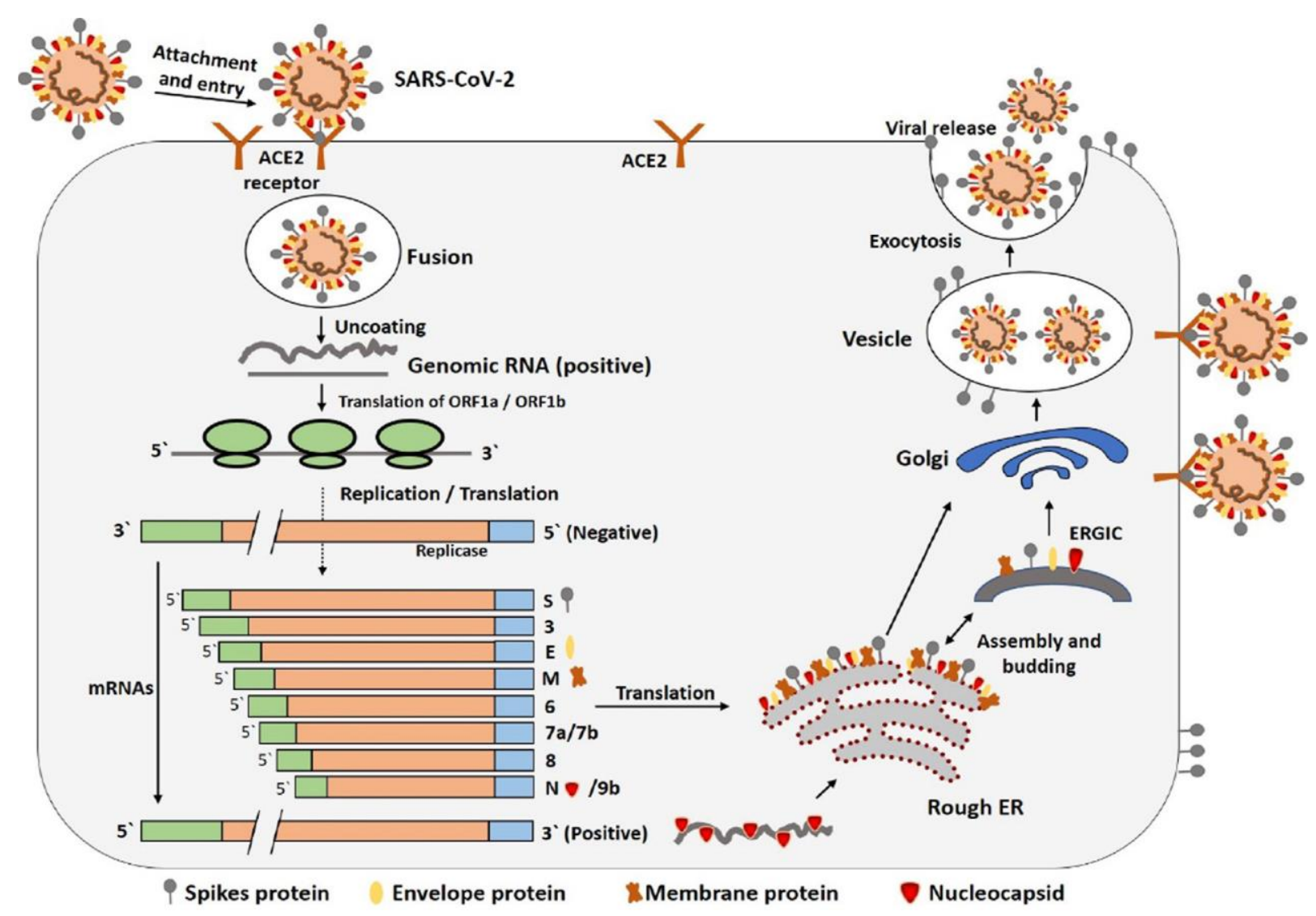

Figure (2): Life cycle of Coronavirus [16].

\section{Chloroquine:}

Chloroquine (CQ) is used as the primary treatment and prevention of malaria. Malaria has its effects on public health, and there are certain types of malaria that require different medicines. It is used to treat amebiasis that occurs outside the intestine, Rheumatoid arthritis and lupus erythematosus. Since it has not been formally studied during pregnancy, it appears to be safe. Also it is working on a cure for COVID-19 as of 2019. The treatment is given by oral administration. Loss of appetite, diarrhea and rashes are among the most common side effects, but serious effects include vision problems, muscle damage, seizures and low levels of blood cells.

Chloroquine (CQ) and hydroxychloroquine (HCQ) are anti-virus and have enormous range of activities (including retroviruses, viruses and coronaviruses) [17-18]. Their antiviral activity against SARS-CoV2 expected to be weak as predicted unbound concentrations of CQ and HCQ in vivo with currently recommended doses are lower than the half-maximal effect 
concentrations reported in cultures of viral cells [19]. Higher doses have been tried than those given for treatment of malaria or amebiasis [20,21]. Chloroquine is very dangerous when using with overdose and led to suicide. In addition, using chloroquine at high levels causes a decrease in regular blood pressure, as well as irregular heart rhythm and coma, acute respiratory distress syndrome and fatal cardiac arrest [22-24].

\section{Meclizine:}

Meclizine is one of the most important $\mathrm{H} 1$ antihistamines as well as an antiemetic and anti-vertigo. The $\mathrm{H} 1$ receptor is defined as a histamine receptor belonging to the rhodopsin family as the G-protein paired receptor. These receptors are activated by the biosynthetic histamine amine. It is expressed in the central nervous system, in vascular endothelial cells, in the heart and in smooth muscles. The $\mathrm{H} 1$ receptor is attached to the intracellular $\mathrm{G}$ protein that activates phospholipase-C and the inositol triphosphate (IP3) signalling pathway. Antihistamines that act on this receptor are used as anti-allergic drugs [25]. It is used to treat both the symptoms of motion sickness and control vertigo associated with diseases of the vestibular system.

$\mathrm{H} 1$ antagonists are also called H1 blockers, as they are drugs that block the action of histamine at the $\mathrm{H} 1$ receptors, and this reduces allergic reactions. Antihistamines are known as agents that have a therapeutic effect mediated by the negative modification of histamine receptors. Other agents may have an antihistamine effect but they are not true antihistamines [26].

Among the distinguishing characteristics of meclizine, it has anticholinergic, central nervous system depressant and local anaesthetic effects. Anticholinergic can be defined as a group of substances that block the action of the neurotransmitter acetylcholine (ACh) in the synapses of the central and peripheral nervous system, or in another way, the neuromuscular junction. These agents block parasympathetic nerve impulses by selectively blocking the neurotransmitter acetylcholine binding to its receptors in nerve cells. Nerve fibres are responsible for the involuntary movement of smooth muscles found in the digestive system, urinary tract, lungs and many other parts of the body. Anticholinergics can be classified into two classes according to their specific targets in the central and peripheral nervous system as well as neuromuscular junction: antimuscarinic agents and anti-nicotine agents. [27].

\section{Pyridoxine Hydrochloride:}

Pyridoxine is a form of vitamin B6, which is a water-soluble vitamin found in many foods. Vitamin B6 is important for many biological systems within the body. It is known that microorganisms and plants have the ability to synthesize peroxidine through self-biological 
processes and animals get it through their diet. In the body pyridoxine is converted into pyridoxal 5-phosphate, which is an essential enzyme for the synthesis of amino acids and neurotransmitters (serotonin and norepinephrine). Vitamin B6 is used to treat neurological disorders and in the treatment of certain genetic disorders such as xanthurenic acid, hyperoxaluria and homocystinuria.

This vitamin obtained from dietary sources, but peroxidine should be consumed when it is low in the body. Some people who eat a healthy diet do not need an excess of vitamin B6. Low levels of vitamin B6 may causes in some cases such as patients with liver disease, alcoholism, hyperthyroidism and heart failure as well as with drugs such as hydralazine, cycloserine, isoniazid and penicillamine.

There was relationship between vitamin B6 and inflammation, a high level of homocysteine was significantly correlated with inflammatory markers (i.e., C-reactive protein, interleukine-6, interleukine- 8 and tumor necrosis factor- $\alpha$ ) through the old people and those with chronic diseases, including cardiovascular disease [28]. High homocysteine levels in the blood help the blood to clot at a high rate. High levels may also cause damage in the lining of the arteries. This leads to the difficulty of blood flow in the blood vessels and then the occurrence of a blockage in the blood vessels. The clot inside the glutamate is called a thrombus. It is worth noting that the clot travels through the bloodstream. Hence, it can be concentrated in the head (which can cause a stroke), the lungs (called a pulmonary embolus) and the heart (which can cause a heart attack). In addition, homocysteine is usually converted into other amino acids for the body to use. One of the most important uses of vitamin B6 is that it helps the body to use homocysteine. When the body's level of vitamin B6 decreases, an increase in homocysteine was occurred.

When homocysteine oxidized, it forms a disulphide bond with another protein or homocysteine once it released from the cell into the circulation by free peroxide radical that released at the same time. [29]. Hence, this could potentially lead to oxidative and nitrogenous stress associated with initiation of inflammation that regulating NF-B transcription [30]. Among the most important factors helping to increase the level of homocysteine in the plasma; genetic mutation and/or nutrient intake. Moreover, vitamin B6 affects the status of homocysteine because it is essential for the metabolism of homocysteine.

Homocysteine is a homologue to amino acid, cysteine and its concentration is associated with proneness to endothelial cell injury and inflammation. For this, there is a close association between chronic plasma amino acid elevation and the risk of developing cardiovascular disease in humans [31] as shown in Figure (3). 


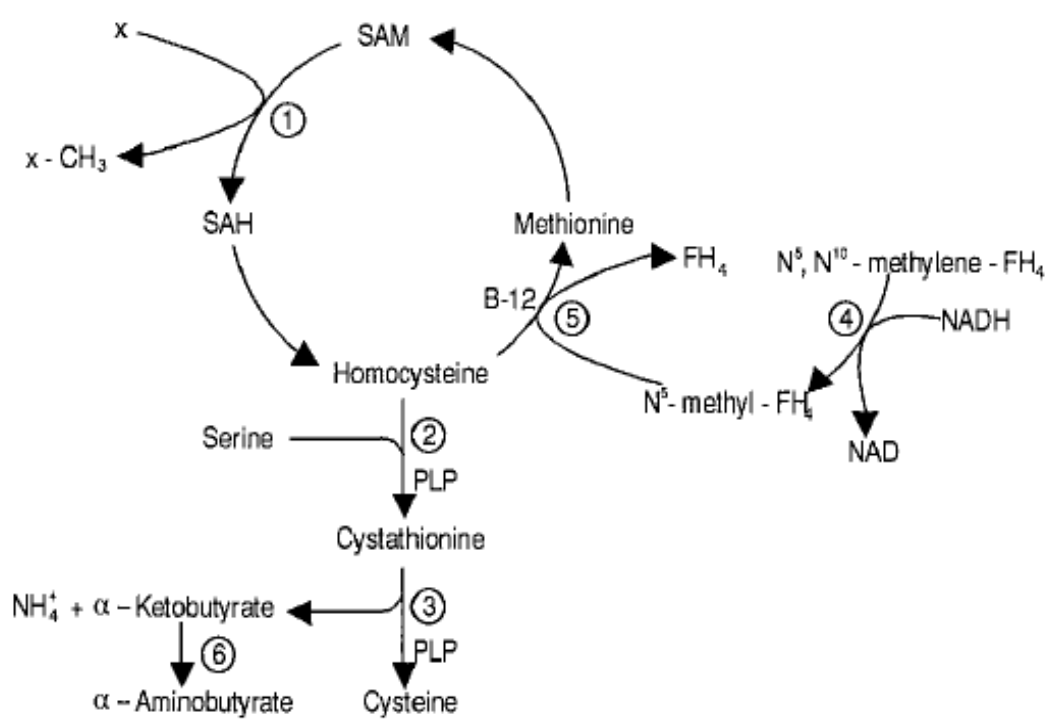

Figure (3): Vitamin B6 and Homocysteine metabolism [32].

Furthermore, atherosclerotic plaques are found in young adults with homocystinuria and those suffering from aggressive arterial, early-onset arterial occlusive disease in addition to venous obstructive disease. Studies have shown that one of the risk factors for cardiovascular and cerebrovascular diseases is plasma concentrations of homocysteine [33]. Elevation in the concentrations of homocysteine in diabetic retinopathy consider secondary to renal disease. In addition, there is a clear relationship between elevated concentrations of homocysteine, retinal vein and arterial occlusion while, the role of homocysteine in relation to ophthalmic diseases remains complex. Recent studies showed that many eye conditions have been found in the general population, such as some forms of glaucoma and age-related macular degeneration, which closely related to elevation in plasma homocysteine. [33-35].

If methionine is not present or deficient due to insufficient vitamin B6, it takes its place. It is called homocysteine or HCY for short. It is normal to have HCY in your body, but when levels get too high it becomes somewhat annoying. For example, one of the implications of high HCY is an increased risk of developing cardiovascular disease [36].

Diaminoxidase (DAO) is an enzyme that plays a major role in histamine metabolism and is responsible for maintaining a constant level of histamine required to balance many of 
the chemical reactions that take place within the body. When vitamin B6 is too low, DAO cannot be produce effectively, vitamin B6 also participates in the formation of DAO. Another significant link between vitamin B6 and histamine intolerance is vitamin B6 role in supporting DAOs function to break down histamine. DAO enzyme works on the breakdown of histamine outside the cell (free), regardless of the origin of the histamine, whether it is from the processes caused by allergies in the body or through food. [37]

\section{Corticosterone:}

Corticosterone is one of the glucocorticoid hormones, which play an important role in the response and organic modifications to the change occurs in environmental [38]. Glucocorticoids have fundamental effects on various systems, which confuse a direct interpretation of hypothalamo-pituitary-adrenal (HPA) axis regulation. The direct effect of Glucocorticoids is to stimulate glucose formation in the liver, so that glucose is released in the blood, which improves the metabolism process as it becomes available to all body tissues and organs. [39].

Corticosterone is a 21-hydroxy steroid that contains pregn-4-ene substituted by hydroxy groups at positions 11, 21, and Oxo groups at positions 3 and 20. It is a 21-carbon steroid hormone of the corticosteroid type produced in the cortex of the adrenal glands [40]. It has a role as a human metabolite and a mouse metabolite. It derives from a hydride of a pregnane.

Aldosterone is formed as a result of corticosterone conversion, which is a major biosynthetic pathway for mineralocorticoids. Aldosterone is formed from corticosterone in the human adrenal cortex by the enzymes CYP11B1 (11ß-hydroxylase) and CYP11B2 (aldosterone synthase), respectively (Figure, 4) [41].

One of the most important functions of aldosterone is the maintenance of sodium in the kidneys and salivary glands, as well as the colon and sweat glands. It has an essential role in regulating blood pressure, plasma sodium levels $\left(\mathrm{Na}^{+}\right)$, and potassium $\left(\mathrm{K}^{+}\right)$levels. It acts on the mineralocorticoid receptors in the distal tubules and collecting ducts of the nephron. Also, aldosterone acts on the re-absorption of sodium as well as the excretion of potassium through tubular fluids, respectively in the kidneys, so it indirectly affects water retention or loss, blood pressure and volume. When aldosterone is released from controls, it may be the reason for cause of disease and contribute to the development of cardiovascular and kidney disorder. 


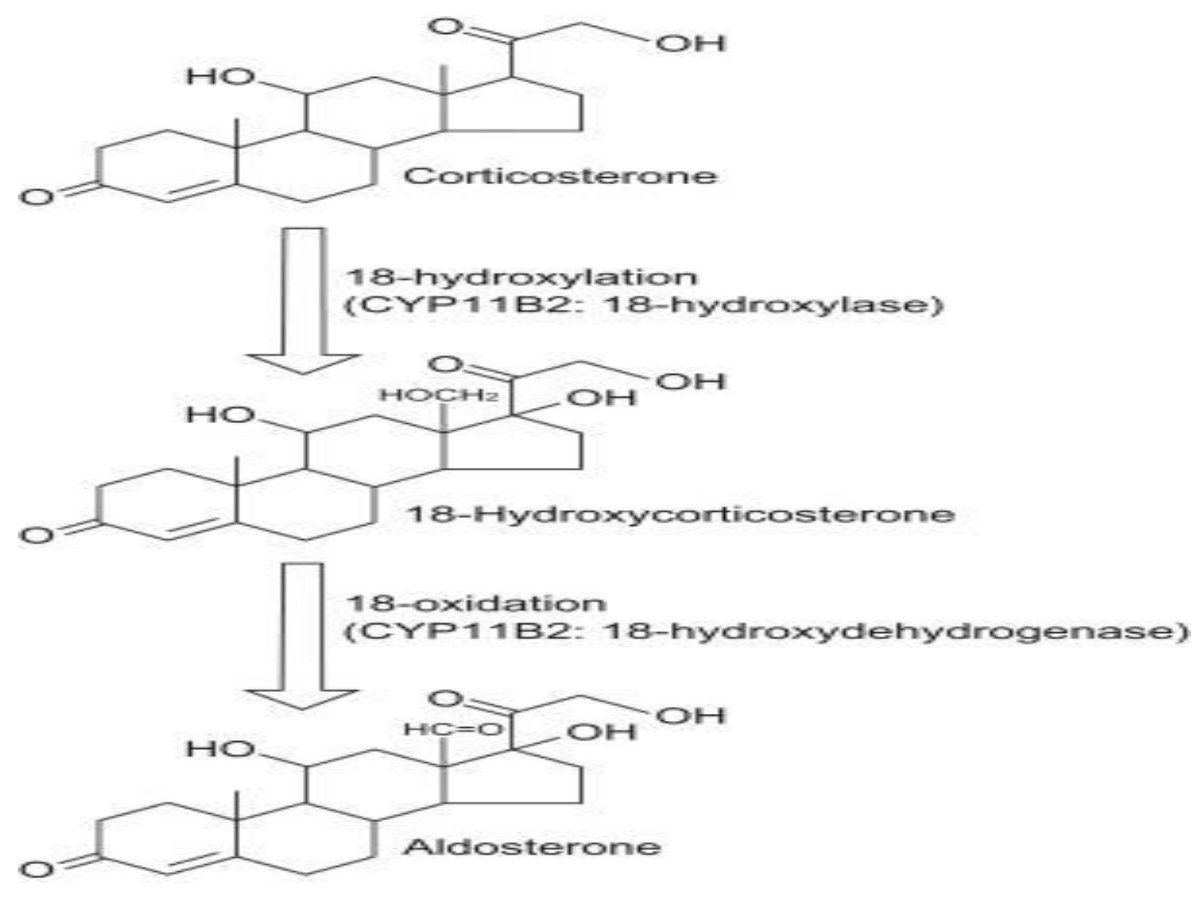

Figure (4): Synthesis of 18-OHB. [42].

\section{Experimental design:}

According to [43] this experiment was designed to develop an optimal protocol for treating the coronavirus, as follows:

- $25 \mathrm{mg}$ of meclizine hydrochloride

- $50 \mathrm{mg}$ pyridoxine hydrochloride

- $100 \mathrm{mg}$ chloroquine

- $50 \mathrm{mg}$ corticosterone

\section{Conclusion}

On the basis of previous investigations, chloroquine has been proved to have antiviral effect and potential mechanism in medical laboratory. The combination between meclizine, pyridoxine hydrochloride and corticosterone together with chloroquine are more effective in coronavirus symptoms than chloroquine only. Addition of chloroquine and corticosterone to their therapeutic role can block the undesirable effects for coronaviruses. Therefore, using a mixture of chloroquine and corticosterone in the presence of meclizine plus pyridoxine hydrochloride improve the pharmadynamic and pharmakinetic properties of chloroquine and act together to decrease the harmful side effects of Coronaviruses. Therefore, this study can practically help to encourage the clinical use of this compound as a prevention or treatment for coronavirus. 


\section{References:}

[1] Caly, L.; Druce, J.D.; Catton, M.G.; Jans, D.A. \& Wagstaff, K.M.,"The FDA- approved drug ivermectin inhibits the replication of SARS-CoV-2 in vitro", Antiviral Res. 104:(2020) $787-810$

[2] Lim, Y.X.; Ng, Y.L.; Tam, J.P. \& Liu, D.X. ,"Human Coronaviruses: A review of VirusHost interactions", Diseases, 4: (2016) 120-128

[3] Zhu, N.; Zhang, D.; Wang, W.; Li, X.; Yang, B.; Song, J.; Zhao, X.; Huang, B.; Shi, W.\& Lu, R.,"A Novel coronavirus from patients with pneumonia in china", N. Engl. J. Med., 12: ( 2019) 651-658

[4[ Drosten, C.; Gunther, S.; Preiser, W.; van der Werf, S.; Brodt, H.R.; Becker, S.; Rabenau, H.; Panning, M.; Kolesnikova, L. \& Fouchier, R.A.,"Identification of a novel coronavirus in patients with severe acute respiratory syndrome", N. Engl. J. Med.,348: .( 2003)1967-1976.

[5] Zaki, A.M.; van Boheemen, S.; Bestebroer, T.M.; Osterhaus, A.D. \& Fouchier, R.A., "Isolation of a novel coronavirus from a man with pneumonia in Saudi Arabia", N. Engl. J. Med., 367: (2012) 1814-1820

[6] Fehr, A.R. \& Perlman, S. ,"An overview of their replication and pathogenesis" Methods Mol. Biol., 1282: (2015) 1-23.

[7] Bosch, B.J.; van der Zee, R.; de Haan, C.A. \& Rottier, P.J.,"The coronavirus spike protein is a class I virus fusion protein: Structural and functional characterization of the fusion core complex", J. Virol, 77: (2003) 8801-8811.

[8] Izaguirre,G.,"the Proteolytic Regulation of Virus Cell Entry by Furin and Other Proprotein Convertases",Viruses, 11: (2019) 837-855

[9] Bosch, B.J.; Bartelink, W. \& Rottier, P.J. ,"Cathepsin L functionally cleaves the severe acute respiratory syndrome coronavirus class I fusion protein upstream of rather than adjacent to the fusion peptide", J. Virol.,82: (2008) 8887-8890

[10] Nal, B.; Chan, C.; Kien, F.; Siu, L.; Tse, J.; Chu, K.; Kam, J.; Staropoli, I.; CrescenzoChaigne, B.\& Escriou, N.,"Differential maturation and subcellular localization of severe acute respiratory syndrome coronavirus surface proteins S, M and E., J. Gen. Virol. 86: (2005) 1423-1434

[11] Siu, Y.L.; Teoh, K.T.; Lo, J.; Chan, C.M.; Kien, F.; Escriou, N.; Tsao, S.W.; Nicholls, J.M.; Altmeyer, R.\& Peiris, J.S., "The M, E, and N structural proteins of the severe acute respiratory syndrome coronavirus are required for assembly, tracking, and release of viruslike particles" J. Virol., 82: ( 2008) 11318-11330.

[12] Hurst, K.R.; Koetzner, C.A. \& Masters, P.S. ,"Identification of in vivo-interacting domains of the murine coronavirus nucleocapsid protein"J. Virol, 83: (2009) 7221-7234.

[13] Klausegger, A.; Strobl, B.; Regl, G.; Kaser, A.; Luytjes, W.\& Vlasak, R. ,"Identification of a coronavirus hemagglutinin-esterase with a substrate specificity different from those of influenza C virus and bovine coronavirus"J. Virol.,73: (2009) 3737-3743. 
[14] Savarino, A.; Boelaert ,J.R.; Cassone, A.; Majori, G.\& Cauda, R.,"Effects of chloroquine on viral infections: an old drug against today's diseases? Lancet Infect "Dis.,3 : (2003) 722733

[15] Muhammad, A .S. ; Suliman ,K. ; Abeer ,K. ;Nadia B. ; Rabeea,S.,"COVID-19 infection: Origin, transmission, and characteristics of human coronaviruses "Journal of Advanced Research ,24: (2020) 91-98

[16] Shereen, M.A.; Suliman, K.; Abeer, K.; Nadia, B. Rabeea, S. ,"COVID-19 infection: Origin, transmission, and characteristics of human coronaviruses" Journal of Advanced Research ,24: (2020) 91-98

[17] Liu, J.; Cao ,R.; Xu ,M.; Wang, X.; Zhang, H.; Hu „H.," Hydroxychloroquine, a less toxic derivative of chloroquine, is effective in inhibiting SARS-CoV-2 infection in vitro" Cell Discov,6: (2020) 16-29

[18] Wang, M.; Cao, R.; Zhang, L.; Yang, X.; Liu, J. \& Xu, M.,"Remdesivir and chloroquine effectively inhibit the recently emerged novel coronavirus (2019-nCoV) in vitro"Cell Res., 30: (2020)269-277.

[19] White, .N.J.; Watson, J.A.; Hoglund, R.M.; Chan, X.H.; Cheah, P.Y. \& Tarning, J.," COVID-19 prevention and treatment: a critical 707 analysis of chloroquin hydroxychloroquine clinical pharmacology"PLOS Medicine, (2020) in press.

[20] World Health Organization, (2015)

[21] Conan, N.J. ,"The treatment of hepatic amebiasis with chloroquine",The American journal of medicine, $623:$ (1949)309-320.

[22] Borba , M.G.S. ; Val, F.F.A. ; Sampaio, V.S. ; Alexandre, M.A.A. ; Melo, G.C. ; Brito, M. ; Mourão, M.P.G. ; Brito-Sousa, J.D. ; Baía-da-Silva, D. ; Guerra, M.V.F. ; Hajjar, .LA. ; Pinto, R.C. ; Balieiro, A.A.S. ; Pacheco, A.G.F. ; Santos, J.D.O. ; Naveca, F.G. ,"Effect of high vs low doses of chloroquine diphosphate as adjunctive therapy for patients hospitalized with severe acute respiratory syndrome coronavirus 2 (SARS595 CoV-2) infection: A randomized clinical trial",JAMA Network Open. 4: (2020)342-355

[23] Riou, B.;Barriot ,P.; Rimailho, A.\& Baud, F.J.,"Treatment of severe chloroquine poisoning", N. Engl.J. Med., 318: (1988) 1-6.

[24] Mégarbane, B.; Bloch, V.; Hirt, D.; Debray,M.; Résiére, D.; Deye, N.\& Baud, F.J.," Blood concentrations are better predictors of chioroquine poisoning severity than plasma concentrations: a prospective study with modeling of the concentration/effect relationships", Clin. Toxicol. 48: (2003) 904-915

[25] de Graaf, C.; Kooistra, A.J.; Vischer, H.F.;Katritch, V.; Kuijer, M.; Shiroishi, M.; Iwata, S.; Shimamura ,T.;Stevens, R.C.; de Esch, I.J.\&Leurs, R. ,"Crystal structure-based virtual screening for fragment-like ligands of the human histamine H(1) receptor", J. Med.Chem., 54 : (2011) 8195-206

[26] Khilnani, G. \& Khilnani, A.K. ,"Inverse agonism and its therapeutic significance",Ind. J. Pharmacol., 43 : (2011) 492-501

[27] Wiggins, S.A. \& Griebling,T.,"Urinary Incontinence", Landon Center on Aging. Archived from the original on 2011, Retrieved ,14: (2011) 07-19 
[28] van den Kommer, T. N.; Dik, M. G.; Comijs, H. C.; Jonker, C.\& Deeg ,D. J. H.," Homocysteine and inflammation: predictors of cognitive decline in older persons. Neurobiology of Aging, J.neurobiolaging 31: ( 2010)1700-1709.

[29] Wu, J. T. ,"Circulating homocysteine is an inflammation marker and a risk factor of lifethreatening inflammatory diseases "J. Biomed. Lab. Sci., 19: (2007)107-111

[30] Li, M.; Chen, J.; Li, Y.-S.; Feng ,Y.-B.; Gu, X.\& Shi, C.Z. ,"Folic acid reduces adhesion molecules VCAM-1 expession in aortic of rats with hyperhomocysteinemia", International Journal of Cardiology,106: (2006)285-288

[31] Clarke, R., L.; Daly, K.; Robinson, E.; Naughten, S.; Cahalane, B.; \& Graham, I. ,"Hyperhomocysteinemia: an independent risk factor for vascular disease", N. Engl. J. Med. 324: (1991) 1149-1155.

[32] Johan, B.; Ubbink, A.; Annatjie, V.; Rhena, D.; Robert, H.; \& Vermaak,E.,"Vitamin B6 and Homocysteine Metabolism",J. Clin. Invest., 98: (1996) 177-184

[33] Soedamah, M.S.S.; Chaturvedi, N.; Teerlink, T.; Idzior, W.R.; Fuller ,J.H.\& Stehouwer, C.D.A.," Plasma homocysteine and microvascular and macrovascular complications in type 1 diabetes: A cross-sectional nested case control study", J Intern Med., 258: (2005) 450-459

[34] Looker, H.C.; Fagot, C.A.; Gunter, E.W.; Pfeiffer, C.M.; Narayan ,K.M.V.\& Knowler, W.C. ,"Homocysteine as a risk factor for nephropathy and retinopathy in Type 2 diabetes", Diabetologia, 46: (2003)766-772

[35] Yuecel, I.; Yeucel, G. \& Mueftueoglu, F. ,"Plasma homocysteine levels in noninsulindependent diabetes mellitus with retinopathy and neovascular glaucoma",Int Ophthalmol.,25: (2004)201-205

[36] Yoshikaw, T. ,"Histamine N-Methyltransferase in the Brain",Int. J. Mol. Sci., 20: (2019) 737-758

[37] Ede, G. ,"Histamine Intolerance: why freshness matters",J. Evol. Health2 ,1: (2020) 2339

[38] McEwen, B. S. \& Wingfield, J. C. ,"the concept of allostasis in biology and biomedicine", Horm Behav 43: (2003) 2-15

[39] Remage-Healey, L. \& Romero, L. M. ,"Daily and seasonal variation in response to stress in captive starlings Sturnus, glucose", Gen Comp Endocrinol. 119: (2000) 60-68.

[40] Hill, R.A.; Makin, H.L.J.; Kirk, D.N. \& Murphy. G.M.,"Dictionary of Steroids",189: (1991) 978-990.

[41] Romeo, R. D., Tang, A. C., \& Sullivan, R. M.,"Early life experiences: Enduring behavioral, neurological and endocrinological consequences. In D. W. Pfaff\& A. M. Etgen (Eds.)",Molecular mechanisms of hormone actions on behavior.12: (2009)543-572.

[42] Eduardo, N.; Cozza, B.; Matkovic, C. ,"in Handbook of Hormones", (2016) : 529-530

[43] Priti, N.; \& Emily M. ,"Meclizine: Safety and Efficacy in the Treatment and Prevention of Motion Sickness", Clinical Medicine Insights: Therapeutics,3: (2011) 179-183 


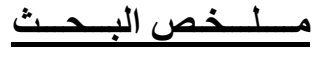 \\ منى اسماعيل شاهين \\ قسم علم الحيوان -كلية البنات - جامعة عين شمس هلين}

فيروسات كورونا هي عائلة كبيرة من فيروسات الحمض النووي الريبي حيث انها تتسبب في العديد من الأمراض. يتفاوت المرض من خفيف الى أكثر خطورة في معظم الناس. قد يتطور هذا المرض إلى التهاب رئوي

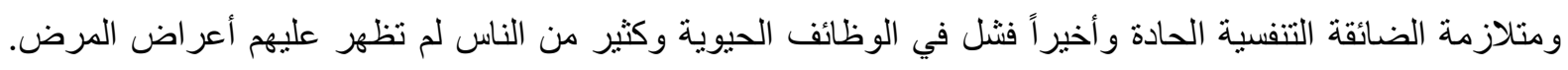
النتائج المخبرية السريرية اثتتت ان الاصدابة بالمرض ينتج عنه انخفاض في عدد خلايا الدم البيضاء مع ارتفاع في معدل بروتين سي التفاعلي. يعتبر الكلوروكين مضاد للفيروسات وله نأثيرات إيجابية على العدوى الفيروسية للخلايا البدائية. بالإضافة إلى هلى ذللك، لوحظت هذه التأثيرات المثبطة عند استخدام الدواء قبل وبعد التعرض للفيروس، و هذا مهم لكل من الهندسة الوقائية و العلاجية وكذللك الميزة العلاجية للكلوروكين. يعتبر الميكليزين وهيدروكلوريد البيريدوكسين من مضادات الالتهابات القوية، مما يساعد في السيطرة على عاصفة السيتوكين. العلاج بخليط من الكلوركين والكورتيكوستيرون و الميكليزين و البيريدوكسين قد يقي من تجلط الدم، مما يحد من انتشار المرض. وفقًا لذلك، يمكن استخدام الكلوروكين و الكورتيكوستيرون و الميكليزين مع البيريدوكسين للوقاية و العلاج من الالتهابات الفيروسية المسبية للأمر اض. 